\title{
Aerobic bacterial microbiota of the conjunctiva in diabetic patients with normal and altered glycated hemoglobin levels in two regions in Brazil
}

\author{
Microbiota bacteriana aeróbica conjuntival em pacientes diabéticos com hemoglobina glicada normal e \\ alterada em duas regiões brasileiras
}

Natalia Pimentel Morenoํㅡ, Renaldo Duarte Moreno², Luciene Barbosa Sousa ${ }^{3}$

\begin{abstract}
Purpose: To study the aerobic bacterial microbiota of the conjunctiva in diabetic patients with regard to the management of diabetes, assessed using glycated hemoglobin levels.

Methods: A cross-sectional study was conducted using conjunctival smears of diabetic patients from both sexes and with different ages, residing in two different Brazilian cities (Sorocaba and Rio Branco). A control group of non-diabetic patients was also included. The diabetic patients were considered to have controlled diabetes when their glycated hemoglobin level was $\leq 7 \%$ and blood glucose leve was $\leq 126 \mathrm{mg} / \mathrm{dL}$. Patients with non-controlled diabetes were those with glycated hemoglobin levels $>7 \%$ and blood glucose levels $>126 \mathrm{mg} / \mathrm{dL}$. The samples obtained were inoculated in Brain-Heart Infusion broth and in culture media for aerobic bacteria (blood and chocolate agars); bacterial growth was evaluated in a microbiology laboratory.

Results: A total of 120 eyes of 120 patients were included in the present study. The percentage of cultures in which bacterial growth was observed was greater in diabetic patients, although the difference was not statistically significan $(p=0.103)$. There was a greater trend toward bacterial growth in the conjunctiva of diabetic patients with altered fasting blood glucose. There was no difference in the frequency of bacterial growth on the conjunctiva between diabetic patients with normal or altered glycated hemoglobin levels. In Sorocaba, conjunctival bacterial growth was similar to that observed in Rio Branco. The microorganism most frequently detected in the present study was Staphylococcus epidermidis, followed by Staphylococcus aureus, Proteus mirabilis, and Escherichia coli.

Conclusions: There was no difference between diabetic patients with normal or altered glycated hemoglobin levels. The microorganisms found were similar to those found in studies investigating the conjunctival bacterial flora of diabetic and non-diabetic patients.
\end{abstract}

Keywords: Conjunctiva; Microbiota; Diabetes mellitus; Hemoglobin A, glycosylated

\section{RESUMO}

Objetivo: Estudar a microbiota conjuntival bacteriana aeróbica dos pacientes diabéticos em relação ao controle glicêmico, verificado através da hemoglobina glicada, em duas cidades distintas.

Métodos: Foi realizado um estudo transversal utilizando raspados de conjuntiva de indivíduos diabéticos de ambos os sexos e idades variáveis de duas cidades: Sorocaba e Rio Branco. O grupo controle foi constituído de pacientes não diabéticos. A amostra foi constituída de pacientes diabéticos que foram considerados controlados $\mathrm{com}$ hemoglobina glicada $\leq 7 \%$ e glicemia de jejum $\leq 126 \mathrm{mg} / \mathrm{dl}$ e não controlados $\mathrm{com}$ hemoglobina glicada $>7 \%$ e glicemia de jejum $>126 \mathrm{mg} / \mathrm{dl}$. O material obtido foi semeado em meio líquido Brain Heart Infusion (BHI) e em meios de cultivo para bactérias aeróbicas (ágar sangue e ágar chocolate). O crescimento bacteriano foi avaliado em laboratório de microbiologia.

Resultados: Foram incluidos 120 olhos de 120 pacientes. A porcentagem de culturas nas quais houve crescimento bacteriano foi maior em pacientes diabéticos, sendo a diferença não estatisticamente significante $(p=0,103)$. Não houve diferença entre o crescimento bacteriano em pacientes com hemoglobina glicada normal e alterada. Houve uma tendência maior de crescimento bacteriano em conjuntivas de pacientes diabéticos com glicemias dejejum elevada. Em Sorocaba houve crescimento bacteriano conjuntival semelhante a Rio Branco. O microrganismo mais frequente encontrado neste estudo foi Staphylococcus epidermidis, seguido de Staphylococcus aureus, Proteus mirabilis e Escherichia coli.

Conclusões: Não ocorreu diferença entre pacientes diabéticos com hemoglobina glicada normal e alterada. Os microrganismos encontrados foram semelhantes aos estudos da flora bacteriana de conjuntivas normais e de diabéticos.

Descritores: Conjuntiva; Microbiota; Diabetes mellitus; Hemoglobina A glicosilada

\section{INTRODUCTION}

The human microbiota is one of the areas responsible for the interaction of organism and environment ${ }^{(1-3)}$. Enabling factors, such as diabetes mellitus, may affect the growth of human conjunctival microbiota, increasing the risk of eye infection ${ }^{(4)}$

Diabetes mellitus is a group of metabolic diseases resulting from defects in insulin action and secretion, leading to a hyperglycemic state ${ }^{(5)}$. Measurement of glycated hemoglobin is the gold-standard test in the assessment of glycemic control in patients with diabetes mellitus and is a useful test in the follow-up of diabetic patients, as well as in the assessment of the status of blood glucose over the previous 3 months $s^{(6,7)}$. The correlation of glycated hemoglobin values with fasting blood sugar values is still not well defined ${ }^{(8,9)}$. Values of fasting blood sugar have a better association with glycated hemoglo-
Funding: No specific financial support was used for this study.

Disclosure of potential conflicts of interest: None of the authors have any potential conflicts of interest to disclose.

Corresponding author: Natalia Pimentel Moreno. Rua Floriano Peixoto, 335 - Rio Branco, AC 69900-025 - Brazil - E-mail: npmoreno@uol.com.br

Approved by the following Research Ethics Committee: Federal University of São Paulo (UNIFESP) (0115/09). 
bin values when they are higher, i.e., in situations of poor glycemic control ${ }^{(7,8)}$.

Studies show that the bacterial flora of healthy individuals is formed by Staphylococcus epidermidis(4,10,11), S. aureus, Corynebacterium sp, and Propineobacterium acne ${ }^{(13)}$. S. epidermidis, S. aureus, and Corynebacterium sp have also been found in diabetic patients ${ }^{(4)}$.

Variations in conjunctival microbiota may occur due to both intrinsic and extrinsic changes in the body, such as geographical diversity and different socioeconomic characteristics (4,10,12-14) $^{\text {Therefore, }}$ the conjunctival aerobic microbiota of diabetic patients was studied in two different Brazilian cities: Rio Branco, in the state of Acre, in north Brazil; and Sorocaba, in the state of São Paulo, in southeastern Brazil. Rio Branco has a largely equatorial climate, while Sorocaba has a subtropical climate. They are significantly different in terms of social and economic development, as Rio Branco has an agriculture-based economy, while Sorocaba is located in a burgeoning industrial sector ${ }^{(15,16)}$. Based on such climate and socioeconomics differences, the bacterial flora of diabetic and non-diabetic patients was studied in these two regions.

Although the literature also demonstrates the presence of anaerobic bacteria and fungi, the object of the current study was to evaluate the aerobic bacteria in this context $\mathrm{t}^{(13,14)}$.

The main aim of the current study was to study aerobic bacterial microbiota in the conjunctiva of diabetic patients in terms of the level of control of diabetes, assessed using glycated hemoglobin levels. It also aimed to analyze the influence of fasting blood sugar on conjunctival bacterial growth in diabetic patients and to study the influence of environmental variations on the aerobic bacterial microbiota in the conjunctiva of diabetic and non-diabetic patients.

\section{METHODS}

A cross-sectional study was performed using smears from the conjunctiva of diabetic patients of both sexes and of different ages, living in the urban areas of two cities, Sorocaba (São Paulo) and Rio Branco (Acre). The study was approved by the Ethics Committee at the Federal University of São Paulo (São Paulo, Brazil) and patients signed an Informed Consent form.

The patients in the present study included individuals with diagnostic confirmation of type 2 diabetes as well as non-diabetic individuals based on clinical history and laboratory tests (previously performed blood glucose test results included in their medical records). The groups were matched according to sex and age. Patients were selected from two different regions (the Acre Teaching Hospital in Rio Branco and the Ophthalmology Hospital of Sorocaba in São Paulo), and were chosen according to sex and age.

The exclusion criteria for both groups were as follows: the presence of eye disease not related to diabetes, such as anatomical or functional lesions of the eyelids, lacrimal system, cornea or conjunctiva, hyperemia and/or conjunctival secretion; use of topical medication or contact lenses within the previous 30 days; or patients with other diseases that could alter the immune response. Patients underwent a review of clinical history and an eye examination via slit lamp biomicroscopy prior to the sample collection for the evaluation of inclusion and exclusion criteria.

A total of three main groups were created: controlled diabetic; non-controlled diabetic and control groups. The diabetic sample consisted of patients who were considered to have controlled diabetes, with glycated hemoglobin levels (hemoglobin A1c fraction) $\leq 7 \%$ and blood glucose levels $\leq 126 \mathrm{mg} / \mathrm{dL}$ (DMc group; controlled diabetic patients); and patients with non-controlled diabetes, with glycated hemoglobin $>7 \%$ and blood glucose $>126 \mathrm{mg} / \mathrm{dL}$ (DMnc group; considered to be non-controlled diabetic patients), according to the American Diabetes Association ${ }^{(17)}$, based on the results of the Diabetes Control and Complications Trial ${ }^{(17)}$ and the United Kingdom Prospective Diabetes Study ${ }^{(18)}$. Patients without diabetes mellitus formed the control group (group C). The group of non-controlled diabetic patients was also evaluated according to the range of fasting blood sugar values: 126 to $140 \mathrm{mg} / \mathrm{dL} ; 141$ to $160 \mathrm{mg} / \mathrm{dL}$; and $>160 \mathrm{mg} / \mathrm{dL}$. Individuals with glycated hemoglobin levels $>7 \%$ and fasting blood glucose levels $<126 \mathrm{mg} / \mathrm{dL}$ were not selected, nor were individuals with glycated hemoglobin levels $<7 \%$ and fasting blood glucose levels $>126 \mathrm{mg} / \mathrm{dL}$. After collecting blood from the patients in order to evaluate glycated hemoglobin and fasting blood sugar, the collection of eye secretions was performed in all patients from each city, under similar environmental conditions, maintaining the same temperature and humidity and without the use of air conditioning. Data collection was performed by the same researcher.

Swabs were used to collect the content from the bottom of the lower conjunctival sac of the right eye using a rotating and gliding motion on the surface of the lower eyelid conjunctiva and at the bottom of the lower conjunctival sac, without touching the eyelid margins and eyelashes, and without the use of anesthetic eye drops. Sterile gloves were used. The samples were inoculated in liquid Brain Heart Infusion medium and in culture media for aerobic bacteria (blood and chocolate agars).

The samples were stored at room temperature and immediately sent to the Microbiology Laboratory of the Santa Casa hospital in Sorocaba, and the Microbiology Laboratory at the Acre Teaching Hospital. Samples were labeled so that the technician had no access to the patients' clinical information. The plates were incubated at $35^{\circ} \mathrm{C}$ for $48 \mathrm{~h}$ and, in the event of bacterial growth, identification was processed in accordance with the criteria established by the Clinical and Laboratory Standards Institute in 2006) ${ }^{(19)}$. Growth of aerobic bacteria was observed. Samples were considered to be negative when no growth was observed in the medium after a period of seven days. For the statistical analysis, SPSS ${ }^{\circledR}$ (Statistical Package for Social Sciences) version 15.0 (SPSS Inc, Chicago, IL, USA) was used and groups were compared using the $\chi^{2}$ test. The null hypothesis was accepted for all analyses at $p \geq 0.05$.

\section{RESULTS}

A total of 120 eyes from 120 patients were included in the study: 60 patients (20 controlled diabetic patients, 20 non-controlled diabetic patients and 20 non-diabetic patients) in each city (Rio Branco and Sorocaba). The mean age in the three groups was 68 years (range 50 to 82 years).

With regard to gender, on evaluating the three study groups (120 patients), the proportion of males and females was 54 (45\%) and 66 (55\%), respectively. No statistically significant difference between the groups was found when they were compared according to gender $(p=0.807)$.

As for the conjunctival culture, it was found that, in the group of diabetic patients, 50 of the 80 diabetic patients (65\%) had a positive culture for aerobic bacteria, whereas this number was 24 (60\%) in the 40 non-diabetic patients, with no statistically significant difference $(p=0.103)$

Table 1 shows bacterial growth in the three groups.

Figure 1 shows the age distribution according to the positive culture results.

With regard to fasting blood glucose levels, three ranges of values were evaluated: 126 to $140 \mathrm{mg} / \mathrm{dL}, 141$ to $160 \mathrm{mg} / \mathrm{dL}$ and $>160 \mathrm{mg} / \mathrm{dL}$ (Table 2).

The distribution of microorganisms found in positive cultures of diabetic and non-diabetic patients is presented in table 3 .

\section{DISCUSSION}

In the present study, the percentage of cultures in which bacterial growth was observed was higher among diabetic patients (83.3\%) compared with non-diabetic patients (80\%), but this difference was not statistically significant ( $p=0.103)$. 
Table 1. Result from conjunctival cultures comparing patients with controlled diabetes, patients with non-controlled diabetes and non-diabetic patients from samples collected in Sorocaba (São Paulo) and Rio Branco (Acre), Brazil, 2010 and 2011

\begin{tabular}{|c|c|c|c|c|c|}
\hline & $\begin{array}{c}\text { Controlled diabetes } \\
\text { n (\%) }\end{array}$ & $\begin{array}{l}\text { Non-controlled diabetes } \\
\qquad \mathbf{n}(\%)\end{array}$ & $\begin{array}{c}\text { Non-diabetic } \\
\text { n (\%) }\end{array}$ & $\begin{array}{l}\text { Total } \\
\text { n (\%) }\end{array}$ & $\mathbf{p}$ \\
\hline \multicolumn{6}{|l|}{ Sorocaba } \\
\hline Positive culture & $15(18.75 \%)$ & $14(17.5 \%)$ & $10(8.33 \%)$ & $39(32.5 \%)$ & 0.910 \\
\hline Negative culture & $5(6.25 \%)$ & $6(7.5 \%)$ & $10(8.33 \%)$ & $21(17.5 \%)$ & 0.910 \\
\hline \multicolumn{6}{|l|}{ Rio Branco } \\
\hline Positive culture & $11(13.75 \%)$ & $10(12.5 \%)$ & $14(11.66 \%)$ & 35 (29.16\%) & 0.639 \\
\hline Negative culture & $9(11.25 \%)$ & $10(12.5 \%)$ & $6(5.00 \%)$ & $25(20.83 \%)$ & 0.639 \\
\hline
\end{tabular}

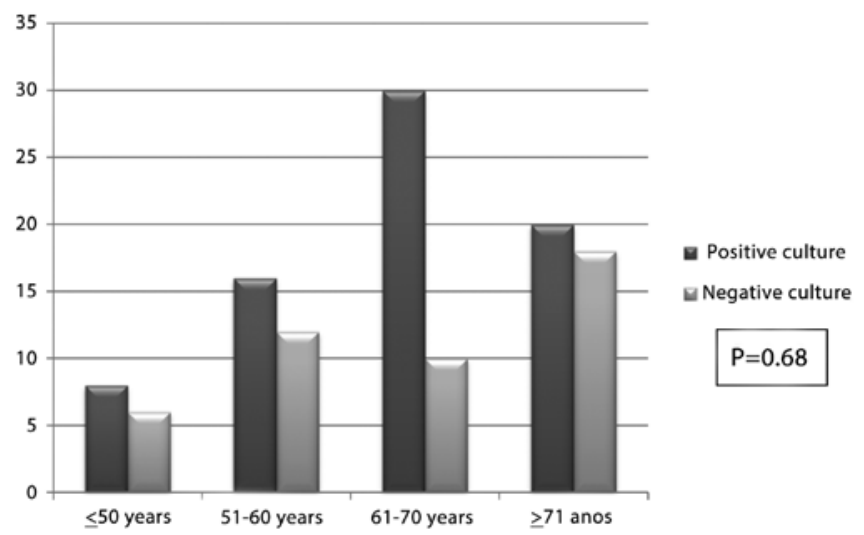

Figure 1. Distribution by age group according to results of a conjunctival culture in diabetic and non-diabetic patients evaluated in Sorocaba (São Paulo) and Rio Branco (Acre), Brazil, 2010 and 2011.

In previous studies, bacterial growth was observed in at least one eye in $94.18 \%$ of the cultures obtained from diabetic patients and in 73.33\% of those obtained from non-diabetic patients ${ }^{(4)}$. The presence of pathogenic microorganisms in the conjunctival microbiota of patients without any evident clinical infection, as observed in the present study, which is associated with the presence of immunological alterations described in this group of individuals, could have the effect of increasing the risk of developing infection following intraocular procedures ${ }^{(20)}$.

When performing an assessment according to age group, a greater number of diabetic and non-diabetic patients were found between 61 and 70 years of age and older than 70 years of age, regardless of glycemic control (patients with controlled and non-controlled diabetes) in the two regions studied, although the difference was not statistically significant. Eyelid changes, poor tear drainage, fragility of the corneal epithelium, decrease in corneal sensitivity and associated comorbidities are only a few of the ocular and systemic features described $^{(21)}$

In a previous study, the bacterial flora of 579 patients was analyzed preoperatively before cataract surgery, along with the isolated bacteria and the percentage of bacterial resistance, and was compared among age groups and according to the presence or absence of diabetes mellitus. In this study, bacterial isolation was lower in patients younger than 40 years of age compared with those older than 60 years of age (61 to 70 years of age; 71 to 80 years of age; and older than 80 years of age), with advanced age being the only significant risk factor in the detection of bacterial growth ${ }^{(22)}$.

Despite immunity, changes described in diabetic patients are related to hyperglycemia ${ }^{(19)}$. In the present study, no differences were observed in the bacterial growth of the conjunctival flora when comparing patients with controlled and non-controlled glycated hemoglobin levels.

When the bacterial flora of the conjunctival sac of patients before cataract surgery was assessed, no significant difference was observed in the rate of bacterial detection among diabetic patients (a total of 197 patients) with regard to glycated hemoglobin levels as well as glycosuria and diabetic retinopathy. The reason for this is unclear, but it is possible that these factors have little influence on conjunctival microbiota. As the microorganisms isolated from the eye, especially from the cornea and conjunctiva, come into direct contact with the environment and originate from the skin of the eyelid, they are influenced by the meibomian glands and endogenous flora; therefore, multiple sources may be responsible ${ }^{(22)}$.

Although glycated hemoglobin level did not have an influence on greater bacterial growth in the samples collected, it was noted that diabetic patients with higher fasting blood glucose levels were more likely to have bacterial growth in their cultures compared with diabetic patients with lower blood glucose levels and with non-diabetic patients. The difference was not statistically significant ( $p>0.05)$, likely due to the small sample size in the present study.

With the data obtained in the present study, it is possible to appreciate the importance of fasting blood glucose levels to bacterial growth because the collection of blood occurred at the same time as the collection of eye secretion. The presence of glucose in the skin, urine, mucous and tears creates a favorable environment for the growth of microrganisms ${ }^{(12)}$ and may also be responsible for the most significant bacterial growth observed in this study.

Any alteration in skin integrity could provide a gateway to infection because of the microbiota that typically colonizes the surface of the human body. The changes found in the microbiota may depend on social and personal factors, on the predominant geographical area, as well as on the resistance that may be present against the empirically administered antibiotics ${ }^{(23)}$. The profile of the ocular microbiota undergoes constant change, influenced by seasonal variations, temperature, age, environmental exposure factors, surgical trauma and host immunity $(4,10,12-14)$.

The characteristics of the two cities studied are, respectively, an equatorial climate with hot and rainy weather in Rio Branco ${ }^{(15)}$, and a subtropical and temperate climate in Sorocaba ${ }^{(16)}$. Located in different regions of Brazil, Sorocaba has a population of 500,000 and large economic diversity ${ }^{(16)}$, in contrast to the city of Rio Branco, which has a population of approximately 350,000 and a barely sustainable economy based on agricultural activities ${ }^{(15)}$. Despite the fact that the literature shows the possible influence of climate and socioeconomic conditions on conjunctival microbiota (bacterial and fungal) ${ }^{(4,10,12-14)}$, no significant differences were observed in the regions studied with regard to bacterial growth.

The most common microorganism found in this study was Staphylococcus epidermidis, followed by Staphylococcus aureus, Proteus mirabilis and Escherichia coli; no significant differences were observed 
Aerobic bacterial microbiota of the Conjunctiva in DiAbetic PATIENTS With Normal AND ALTERED GLyCATED HEMOGLOBIN LEVELS IN TWO REGIONS IN BRAZIL

Table 2. Results of conjunctival cultures from diabetic patients with altered glycated hemoglobin levels according to fasting glycemia, in Sorocaba (São Paulo) and Rio Branco (Acre), Brazil, 2010 and 2011

\begin{tabular}{|c|c|c|c|c|}
\hline & & Fasting glycemia & & $\mathbf{p}$ \\
\hline & $126-140 \mathrm{mg} / \mathrm{dL}$ & $141-160 \mathrm{mg} / \mathrm{dL}$ & $>160$ mg/dL & \\
\hline Positive culture & $5(20.83 \%)$ & $7(29.16 \%)$ & $12(50 \%)$ & 0.158 \\
\hline Negative culture & $6(37.50 \%)$ & $6(37.50 \%)$ & $4(25 \%)$ & $P=0.688$ \\
\hline
\end{tabular}

Table 3. Distribution of microorganisms comparing positive cultures of diabetic and non-diabetic patients evaluated in Sorocaba (São Paulo) and Rio Branco (Acre), Brazil, 2010 and 2011

\begin{tabular}{lcc}
\hline & $\begin{array}{c}\text { Diabetic } \\
\text { CFU (\%) }\end{array}$ & $\begin{array}{c}\text { Non-diabetic } \\
\text { CFU (\%) }\end{array}$ \\
\hline Staphylococcus epidermidis & $41(82 \%)$ & $22(91.6 \%)$ \\
Staphylococcus aureus & $7(14 \%)$ & $1(4.2 \%)$ \\
Proteus mirabilis and S. epidermidis & $2(4 \%)$ & - \\
Escherichia coli and S. epidermidis & - & $1(4.2 \%)$ \\
\hline
\end{tabular}

$\mathrm{CFU}=$ colony forming unit.

between patients with controlled and non-controlled diabetes and patients without diabetes in the two regions examined (Sorocaba and Rio Branco).

A study performed on patients with diabetes mellitus showed that the species most commonly found in the microbiota of diabetic patients, in descending order, were: coagulase-negative Staphylococcus (mainly Staphylococcus epidermidis), Corynebacterium sp and Staphylococcus aureus ${ }^{(4)}$. In the present study, the species of bacteria isolated in the cultures of the conjunctiva of diabetic patients were no different from those identified in the conjunctiva of non-diabetic patients, as was also observed in the study by Martins et al. ${ }^{(4)}$ In normal bacterial flora, the aerobic agents most commonly found are Staphylococcus epidermidis, Staphylococcus aureus, Corynebacterium spp and Propionibacterium acne ${ }^{(4,12)}$. Most studies agree that Staphylococcus epidermidis is the microorganism most commonly found in aerobic bacterial flora of normal conjunctivas $s^{(4,10,11,24)}$.

Greater aerobic bacterial growth was also observed in the conjunctivas of the older patients, regardless of gender or the presence or absence of diabetes. An increased aerobic bacterial growth was observed in patients with altered fasting blood glucose levels at the time of examination, and no difference was observed in aerobic bacterial growth in diabetic patients in relation to glycated hemoglobin levels at the time of collection. There was no difference between the two regions evaluated in any aspect of the study. The microorganisms found were similar to those found in studies on bacterial flora of normal conjunctivas and of diabetic patients, and Staphylococcus epidermidis was the main aerobic bacteria found.

\section{REFERENCES}

1. Savage DC. Mucosal microbiota. In: Ogra PL, Mestecky J, Lamm ME, Strober W, Bienenstock J, McGhee J, editors. Mucosal immunology. New York: Academic Press; 1999. p.19-30.

2. Berg RD. Bacterial translocation from the gastrointestinal tract. Trends Microbiol. 1995:3(4):149-54

3. Minnaard J, Lievin-Le MV, Coconnier MH, Servin AL, Pérez PF. Disassembly of F-actin cytoskeleton after interaction of Bacillus cereus with fully differentiated human intestinal Caco-2 cells. Infect Immun. 2004;72(6):3106-12.
4. Martins EN, Alvarenga LS, Hofling-Lima AL, Freitas D, Zorat-Yu MC, Farah ME, et al. Aerobic bacterial conjunctival flora in diabetic patients. Cornea. 2004:23(2):136-42.

5. Pimazzoni Netto A, Andriolo A, Fraige Filho F, Tambascia M, Gomes MB, Melo M et al. Atualização sobre hemoglobina glicada $(\mathrm{HbA} 1 \mathrm{c})$ para avaliação do controle glicêmico e para o diagnóstico do diabetes: aspectos clínicos e laboratoriais. J Bras Patol Med Lab. 2009:45(1):31-48.

6. Basevi V, Di Mario S, Morciano C, Nonino F, Magrini N. Comment on: American Diabetes Association. Standards of medical care in diabetes-2011. Diabetes Care. 2011;34 (Suppl 1):S11-61. Diabetes Care. 2011;34(5):e53; author reply e54. Erratum in: Diabetes Care. 2011:34(8):1887.

7. Gross JL, Silveiro SP, Camargo JL, Reichelt AJ, de Azevedo MJ. Diabetes melito: diagnóstico, classificação e avaliação do controle glicêmico. Arq Bras Endocrinol Metab. 2002;46(1):16-26.

8. Sartori MS, Aragon FF, Padovani CR, Pimenta WP. Contribuição da glicemia pós-desjejum para o controle glicêmico do paciente com diabetes melito tipo 2. Arq Bras Endocrinol Metab. 2006:50(1):53-59.

9. Monnier L, Lapinski H, Colette C. Contributions of fasting and postprandial plasma glucose increments to the overall diurnal hyperglycemia of type 2 diabetic patients: Variations with increasing levels of HbA1c. Diabetes Care. 2003;26(3):881-5.

10. Araújo ME, Scarpi MJ. Microbiota bacteriana da conjuntiva de doadores de córnea. Arq Bras Oftalmol. 2004;67(6):927-33.

11. Souza LB, Lima AL. Flora ocular normal. In: Lima AL, Nishiwaki-Dantas M, Alves MR. Manual do CBO: doenças externas oculares e córnea. Rio de Janeiro: Cultura Medica. 1999. p.114-3.

12. Bilen $\mathrm{H}$, Ates $\mathrm{O}$, Astam $\mathrm{N}$, Uslu H, Akcay G, Baykal O. Conjunctival flora in patients with type 1 or type 2 diabetes mellitus. Adv Ther. 2007;24(5):1028-35.

13. Libório AM, Dantas MC, Mimica LM, Dantas PE, Lima AL. Microbiota conjuntival em pacientes com alergia ocular. Arq Bras Oftalmol. 2005;68(6):824-7.

14. Santos PM, Melo CM, Martins SA, Chaves AA, Sá DS, Santos RC. Estudo da microbiota fúngica da conjuntiva ocular em portadores de hanseníase e seus comunicantes. Arg Bras Oftalmol. 2006;69(6):915-8.

15. Acre. Governo do Estado do Acre. Indicadores socioeconômicos [Internet]. Rio Branco. [citado 2007 Jul 20]. Disponível em: http://portal.mec.gov.br/setec/arquivos/pdf/ indicad_ac.pdf

16. Sorocaba [Internet]. Wikipedia: a enciclopédia livre. [citado 2007 Jul 20]. Disponíve em: http://pt.wikipedia.org/wiki/Sorocaba

17. Tenover FC, Moellering RC Jr. The rationale for revising the clinical and Laboratory Standards Institute vancomycin minimal inhibitory concentration interpretive criteria for Staphylococcus aureus. Clin Infect Dis. 2007:44(9):1208-15.

18. Tuner R, Cull C, Holman R. United Kingdom Prospective Diabetes Study 17: a 9-year update of a randomized, controlled trial on the effect of improved metabolic control on complications in non-insulin-dependent diabetes mellitus. Ann Intern Med. 1996; 124(1 Part 2):136-45

19. Rohlfing CL, Wiedmeyer HM, Little RR, England JD, Tennill A, Goldstein DE. Defining the relationship between plasma glucose and $\mathrm{HbA}(1 \mathrm{c})$ : analysis of glucose profiles and $\mathrm{HbA}(1 \mathrm{c})$ in the Diabetes Control and Complications Trial. Diabetes Care. 2002; 25(2):275-8.

20. Grice EA, Snitkin ES, Yockey LJ, Bermudez DM; NISC Comparative Sequencing Program, Liechty KW, Segre JA. Longitudinal shift in diabetic wound microbiota correlates with prolonged skin defense response. Proc Natl Acad Sci U S A. 2010;107(33):14799-804. Erratum in: Proc Natl Acad Sci USA. 2010;107(41):17851.

21. Passos RM, Cariello AJ, Yu MC, Höfling-Lima AL. Ceratite infecciosa em idosos: revisão de 32 anos. Arq Bras Oftalmol. 2010;73(4):315-319.

22. Suto C, Morinaga M, Yagi T, Tsuji C, Toshida H. Conjunctival sac bacterial flora isolated prior to cataract surgery. Infect Drug Resist. 2012;5:37-41.

23. Doiz-Artázcoz E, González-Calbo A, Girón-González JA, Bohórquez-Sierra JC Benítez-Rodríguez E, Marín-Casanova P. Empirical antibiotic therapy for diabetic and non-diabetic foot. Angiologia. 2005;57(5):389-400.

24. Tasman W, Jaeger EA. Normal bacterial ocular flora. In: Tasman W, Jaeger E. Duane's clinical ophthalmology. Philadelphia: J.B. Lippincott; 1995. p.18. 